\title{
Conservation of the endemic Javan hawk-eagle Spizaetus bartelsi Stresemann, 1924 (Aves: Falconiformes): density, age-structure and population numbers
}

\author{
S. (Bas) van Balen ${ }^{1}$, Vincent Nijman ${ }^{2}$ \& Resit Sôzzer ${ }^{2}$ \\ ITropical Nature Conservation and Vertebrate Ecology Group, Wageningen Agricultural University, \\ Bornsesteeg 69, 6708 PD Wageningen, The Netherlands. ${ }^{2}$ Institute for Biodiversity and Ecosystem Dynam- \\ ics, Zoological Museum, University of Amsterdam, P.O: Box 94766, 1090 GT Amsterdam, The Netherlands
}

Key-words: birds-of-prey, raptor, forest fragmentation, Java, Indonesia

\begin{abstract}
The endemic Javan hawk-eagle Spizaetus bartelsi is considered threatened with extinction because of its small population size and fragmentation of its habitat on the densely populated island of Java, Indonesia. Like many other tropical forest raptors little is known about many of its population parameters. Research was carried out from 1980 to 2000 in order to assess the status of this species. Its presence was confirmed throughout the island in both wet and dry climatic zones. Home range sizes were calculated to range between $12-36 \mathrm{~km}^{2}$, and comparison with published estimates suggests that these may differ significantly between arès. Encounter rates are in the order of 0.1-0.9 birds per survey day, and were significantly higher in areas with a short dry season compared to areas with a long dry season. Based on field-observations, museum skins and captive birds, the adult: non adult ratio is 1: 1.3. An assessment of habitat quality for all large areas where Javan hawk-eagles have been recorded, and a conservative working density differentiated to habitat quality, lead us to estimate that there are 137-188 remaining pairs, which account for a total world population of just short of a thousand birds. We make a number of suggestions for further research aimed at obtaining more insight on dispersal, recruitment and agerelated habitat preferences, and for improved conservation, including more strict law enforcement and gazettment of new reserves.
\end{abstract}

\section{Contents}

$\begin{array}{ll}\text { Abstract } & 161 \\ \text { Introduction } & 161 \\ \text { Material and methods } & 162 \\ \text { Study area } & 162 \\ \text { Data acquisition } & 164 \\ \text { Determination of densitly } & 164 \\ \text { Age-structure } & 165 \\ \text { Estimate of population numbers } & 165 \\ \text { Statistical analysis } & 166 \\ \text { Results } & 166 \\ \text { Distribution and density } & 166 \\ \text { Age-composition and population size } & 167 \\ \text { Discussion } & 168 \\ \text { Density and age structure } & 168 \\ \text { Population numbers } & 169 \\ \text { Suggestions for further research and improved } & \\ \text { conservation } & 170 \\ \text { Acknowledgements } & 171 \\ \text { References } & 171 \\ \text { Appendix 1 } & 172\end{array}$

\section{Introduction}

The Sundaic region has been identified as one of the hottest biodiversity hotspots on earth, i.e. an area that has lost a high proportion of its primary vegetation and is disproportional rich in plant and vertebrates other than fish (Myers et al., 2000). Among the different parts of the Sundaic region, deforestation and fragmentation is most ancient on the island of Java, Indonesia, with less than $10 \%$ of land cover remaining under forest. The overall destruction of the original lowland vegetation on Java has turned the habitat of Java's rainforest 
specialists into a highly fragmented system of numerous forest patches of varying sizes. Subsequently, some ten rainforest vertebrates are classed as either endangered or critically endangered (Hilton-Taylor 2000; Collar et al. 2001). Among these is the Javan hawk-eagle Spizaetus bartelsi, a tropical forest eagle endemic to the island of Java.

Hardly any data are available on population parameters, demography or population numbers of tropical forest raptors (Thiollay, 1994). Compared to species in temperate regions, especially the larger species are probably long-lived, hold large stable territories throughout the year, typically produce few offspring and may not breed every year, and offspring often have prolonged fledgling periods (Clark, 1994). Given the alarming rate of forest destruction it is widely believed that large animal species, with low fecundity and occurring in restricted ranges (endemics) are especially prone to extinction (McKinney, 1997; Bennett \& Owens 1997; Fagan et al. 2001), and top-predators, including birds of prey, may be the first to disappear (Terborgh, 1988; Davies et al. 2000).

On account of severe habitat fragmentation and small population size the Javan hawk-eagle has for a long time been classed as endangered according to IUCN threat categories (Collar \& Stuart, 1988) whereas more recently the illegal bird trade has been recognised as an additional threat (Sözer and Nijman, 1995; Collar et al., 2001).

Given the Javan hawk-eagle's dependence on relatively large continuous forest areas and given the expected low number of surviving eagles, in order for an accurate status assessment to be made and in order to allow subsequent monitoring, it is essential to have insight in a number of basic population parameters, such as age-structure, densities in different habitats, and population numbers. Unfortunately, like for many other tropical forest raptors, these data are lacking. In order to obtain the relevant data we conducted a number of studies and surveys from 1980 to 2000 . Here we present a new appraisal of status based on original research and a review of the scant published data. The results of the present study have been used in the latest assessment of the Red Data Book for Asian Birds (Collar et al., 2001).

\section{Material and methods}

\section{Study area}

Originally, the island of Java was probably completely covered by tropical forest (MacKinnon et al., 1982), the first major loss of which may have occurred with the introduction of teak Tectona grandis by early Hindus in the 2 nd to 4 th century (Whitten et al., 1996). An estimated total area of $100,000 \mathrm{~km}^{2}$ of natural forest (lowland, hill and montane) was present in the 17th century (Smiet, 1990). About hundred years ago $40,000 \mathrm{~km}^{2}$ was left of this, but this further decreased to about 15,000 $\mathrm{km}^{2}$ in the first half of the 20th century, further decreasing to about $10,000 \mathrm{~km}^{2}$ during the past 50 years (Smiet, 1992). The original vegetation cover is now largely replaced by cities and villages, roads, agricultural land, cash crop plantations (e.g. coffee Coffea spp), forest plantations (teak, pine Pinus merkusil, rubber Hevea brasiliensis), leaving the natural forest areas as habitat islands. Overall, less than $10 \%$ of the original natural forests remain: $54 \%$ of the mountain forest, $19 \%$ of the original hill forest, and only $2 \%$ of the lowland forest (van Balen, 1988; Smiet, 1990; Whitten et al., 1996). The latter forest type is now almost exclusively found scattered along the southern coast and in the easternmost part of the island of Java. Fig. 1 presents the generalised land use cover of the island of Java.

The climate on Java differs greatly along the longitudinal axis of the island. The eastern part of Java and the north coast have a pronounced dry season, while in the western half it is weak and nowhere marked. In general, the wettest vegetation types (mixed lowland and hill rainforest and ever-wet montane forest) only occur in areas with at least 30 rainy days during the driest four consecutive months (van Steenis and SchippersLammertse, 1965), and hence is mostly found in the western and central part of Java. Rain forest is also found throughout the otherwise seasonally dry east in the wet "islands" which arise as a result of cloud stowage on the southern and south-eastern slopes of the higher mountains (van Steenis, 1972). In the drier areas moist forest and deciduous forest replace rainforest. 


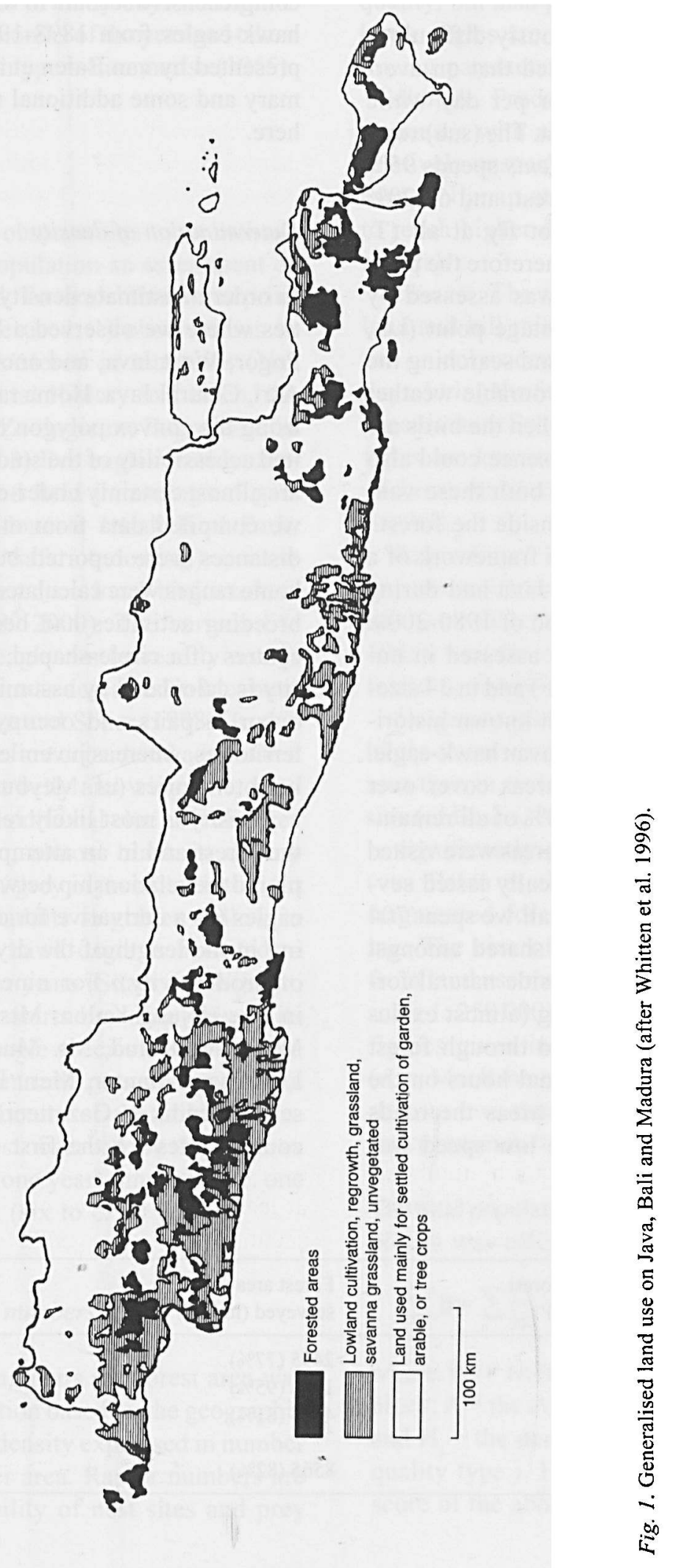




\section{Data acquisition}

Tropical forest eagles are notoriously difficult to observe. Thiollay (1985) estimated that on average he observed only one raptor per day while walking slowly inside the rainforest. The (sub)tropical mountain hawk-eagle $S$. nipalenis spends $95 \%$ of daytime perched inside the forest, and on $20 \%$ of the days observed it does not fly at all (T. Yamazaki pers. comm., 1995). Therefore the presence of the Javan hawk-eagle was assessed by scanning a large area from a vantage point (i.e., hill top, forest edge or opening) and searching the sky and canopy on days with favourable weather between 09.00 and 12.00 hours when the birds are expected to soar and display. Presence could also be assessed by calls heard from both these vantage points and along transects inside the forest.

Observations were made in the framework of $\mathrm{a}$ general study on forest birds on Java and during specialised surveys over the period of 1980-2000. The presence of the species was assessed in numerous small forest areas $\left(<50 \mathrm{~km}^{2}\right)$ and in 34 sizeable forest blocks $\left(>50 \mathrm{~km}^{2}\right)$ with known historical or expected occurrence of the Javan hawk-eagle. In total the investigated forest areas cover over $8500 \mathrm{~km}^{2}$ (see Table 1) or over $80 \%$ of all remaining forest on Java. The majority of areas were visited at least twice, while surveys typically lasted several days up to several weeks. In all we spent 704 field days (10\% of which were shared amongst us) throughout Java surveying inside natural forest (see Table 1). While travelling (almost exclusively by public transport) to and through forest areas we spent numerous additional hours on the look-out for raptors; in forested areas the roads were often so bad that a relative low speed was maintained, allowing observations to be made. A comprehensive account in which all records of Javan hawk-eagles from 1898-1999 were scrutinised is presented by van Balen et al. (1999); a brief summary and some additional new data are presented here.

\section{Determination of density}

In order to estimate density we mapped the localities where we observed a breeding male in Pasir Pogor, West Java, and another adult near Linggo Asri, Central Java. Home range size was estimated using the convex polygon method. Given the limited accessibility of the study areas these estimates are almost certainly under-estimates. Additionally, we compiled data from other researchers. When distances were reported between breeding pairs, home ranges were calculated by assuming that most breeding activities had been taking place in the centres of a circle-shaped, contiguous area. Density is calculated by assuming that all adult eagles occur in pairs and occupy contiguous breeding territories, whereas juveniles and immatures do not hold territories (cf. Meyburg et al. 1994).

Density is most likely related to productivity of the forest and in an attempt to model this we explored the relationship between encounter rate with eagles (as a derivative for density) in areas differing in the length of the dry season (as a measure of productivity). For nine study areas $>50 \mathrm{~km}^{2}$ in size (Ujung Kulon, Mts Halimun, Mts Dieng, Mts Kawi-Kelud, Mt. Murio, Mts Liman-Wilis, Lebakharjo-Bantur, Meru Betiri and Alas Purwo: see Appendix 1: Gazetteer) we calculated the encounter rates for the first 6-8 days of surveying

Table 1. Survey area and survey effort.

\begin{tabular}{|c|c|c|c|c|}
\hline Province & " & $\begin{array}{l}\text { Remaining forest } \\
\left.\text { area (in } \mathbf{k m}^{2}\right)^{\dagger}\end{array}$ & $\begin{array}{l}\text { Forest area } \\
\text { surveyed (in } \mathrm{km}^{2} \text { ) }\end{array}$ & $\begin{array}{l}\text { Survey effort } \\
\text { (in days) }\end{array}$ \\
\hline West Java & & 3163 & 2435 (77\%) & 355 \\
\hline Central Java & & 1365 & $1300(95 \%)^{x}$ & 194 \\
\hline East Java & & 5965 & $4815(81 \%)$ & 155 \\
\hline Total & & 10493 & $8565(82 \%)$ & 704 \\
\hline
\end{tabular}

${ }^{*}$ After MacKinnon et al. (1982) 
under good weather conditions. Dry season was measured by the number of rainy days during the four driest consecutive months of the year and taken from van Steenis and Sçhippers-Lammertse (1965).

\section{Age structure}

In order to extrapolate observations to an estimation of the total wild population an assessment of age structure is required. To model this, three principal data sources were used: 1) observations in the wild; 2) specimens stored in museums (National Museum of Natural History in Leiden, the Netherlands; Museum Zoologicum Bogoriense in Bogor, Indonesia); and 3) live eagles freshly captured from the wild and held in zoological gardens (Taman Mini Indonesia Indah Bird Park, Surabaya Zoo, Taman Safari Indonesia), private collections or encountered on local bird markets (during the period 1989-2000). The various life stages in Javan hawk-eagle can be readily recognised by plumage patterns as described in Meyburg et al. (1989) and Nijman and Sözer (1998). In this paper Javan hawk-eagles are considered adult when the banding patterns on belly and wings are complete. Eye-colour is an additional clue as it changes from very dark brown, almost black in downy chicks, dark blue bluish-grey in juveniles into light grey and lemon in subadults to golden yellow in full adults. The Javan hawk-eagle is believed to mature at an age of four years (Sözer and Nijman, 1995), but most likely starts breeding only in its fifth year, as in other eagle species of comparable size (Newton, 1979; Yamazaki pers. comm., 1990). For modelling age structure of the wild population we classed eagles observed in the field as juveníle (fledgling - c. one year), immature (c. one - five years) and adult (six to c. 20 years).

\section{Estimate of population numbers}

The number of breeding pairs per forest area was calculated by extrapolation based on the geographic area inhabited and the density expressed in number of established pairs per area. Raptor numbers are limited by the availability of nest sites and prey
(Newton 1991), which are determined by habitat quality, but also persecution etc. Density of Javan hawk eagles are therefore determined by the following parameters:

Altitude. Productivity of the tropical rainforest decreases with altitude (Whitten et al., 1996). A relatively unspecialised raptor as the Javan Hawkeagle (Nijman et al., 2000) is therefore expected to reach higher densities at lower elevations (see results).

Climate. The richest forest types - mixed lowland and hill rainforest and montane everwet forest - only occur in areas with at least 30 rainy days during the four driest consecutive months (van Steenis and Schippers-Lammertse, 1965); these types are known to contain the highest densities of Javan hawk-eagle (Meyburg et al., 1989, see results).

Ruggedness. The ruggedness of the area is an important feature for the Javan hawk-eagle as it has been characterised as slope specialist (Wells, 1985). Tall forest on slopes is believed to be preferred to forests on flat plains (see results).

Fragmentation. Javan hawk-eagles are more likely to survive in a large circular-shaped forest area than in an irregularly shaped one of the same size (cf Harris, 1984), and frequency of occurrence is significantly positively correlated to area size (van Balen et al., 2000). Furthermore, eagles in fragmented forest are more susceptible to hunting. The size of forest fragments was measured from land use maps provided by RePPProT (1990: scale 1: 250 000). By comparing these figures with figures given in conservation management plans (e.g., MacKinnon et al., 1982; Whitten et al., 1996) and our own data from the field, we made a qualitative estimate of the available habitat.

The total population of Javan hawk-eagles in $n$ forest blocks was calculated by

$$
\sum_{\mathrm{i}=1}^{\mathrm{n}} \mathrm{B}=\sum \frac{\mathrm{A}}{\mathrm{H}_{\mathrm{i}}}
$$

where $\mathbf{B}=$ Number of breeding pairs per forest block; $A=$ the available habitat in each forest block; and $\mathrm{H}_{\mathrm{j}}=$ the density of pairs occurring in Habitat quality type $\mathrm{j}$. Habitat quality type is the median score of the above described parameters (climate, 
ruggedness and fragmentation) each of which were given a score between 1 ('good") and 3 ('less good").

For areas less than c. $50 \mathrm{~km}^{2}$ and supposed to be too small to support more than two pairs of Javan hawk-eagle we did not estimate area or population size because the inherent error would be proportionally larger.

\section{Statistical analysis}

Since most data collected are not normally distributed or are ordered along an ordinal scale, and as to increase the generality of the conclusions, non-parametric tests were used (Siegel, 1956). Encounter rates in areas differing in length of the dry season were compared with a Mann-Whitney $\mathrm{U}$ test. For testing whether habitat parameters were. independent, and whether there was a bias in survey effort, a Kendall Rank Correlation Coefficient was calculated. Significance was assumed when $\mathrm{p}<0.05$ in a two-tailed test, and trends are mentioned when $0.05<\mathrm{p}<0.10$.

\section{Results}

\section{Distribution and density}

We observed Javan hawk-eagles at 49 localities distributed across 21 forest blocks (van Balen et al. 1999), and during the last two decades other ornithologists have recorded their presence in four additional areas: Jampang (P. Andrew in litt. 1985; Hapsoro pers. comm. 1999), Masigit-Kareumbi, Telaga Bodas - Mt Gelunggung and Mt Sawal (Setiadi et al., 2000), all in West Java; Mt CupuSimembut and Mt Ungaran in Central Java (M. Linsley in litt. 1994), and Mt Bromo/Tengger/ Semeru in East Java (R. Nursaid, pers. comm. 1999; see Appendix 1). Historically (pre-1975) Javan hawk-eagles had been recorded from 18 localities in 11 forest blocks; in two of these areas (one of which has presently no forest left), no recent observations were made of Javan hawk-eagles. For 26 areas observations have been made post-1989, of 18 even as recently as 1995 or later. All forest areas in which we observed Javan hawk-eagles in the early stages of our survey still contained the species in the latter stages. Our survey effort is significantly correlated with forest area size (Kendall Rank Correlation Coefficient, $\tau=0.37$, $\mathrm{p}<0.03$ ) but not with climate, ruggedness or fragmentation (Kendall Rank Correlation Coefficient, all $p>0.10$ ), i.e. in general we spent more time surveying in large forest areas compared to smaller ones but this was not related to the physical condition of the terrain.

There is a preponderance of birds occurring in areas with highest rainfall (type 1 in Table 2), and only occasionally were birds encountered in rather dry

Table 2. Densities of Javan Hawk-eagles. Sites are listed from west to east

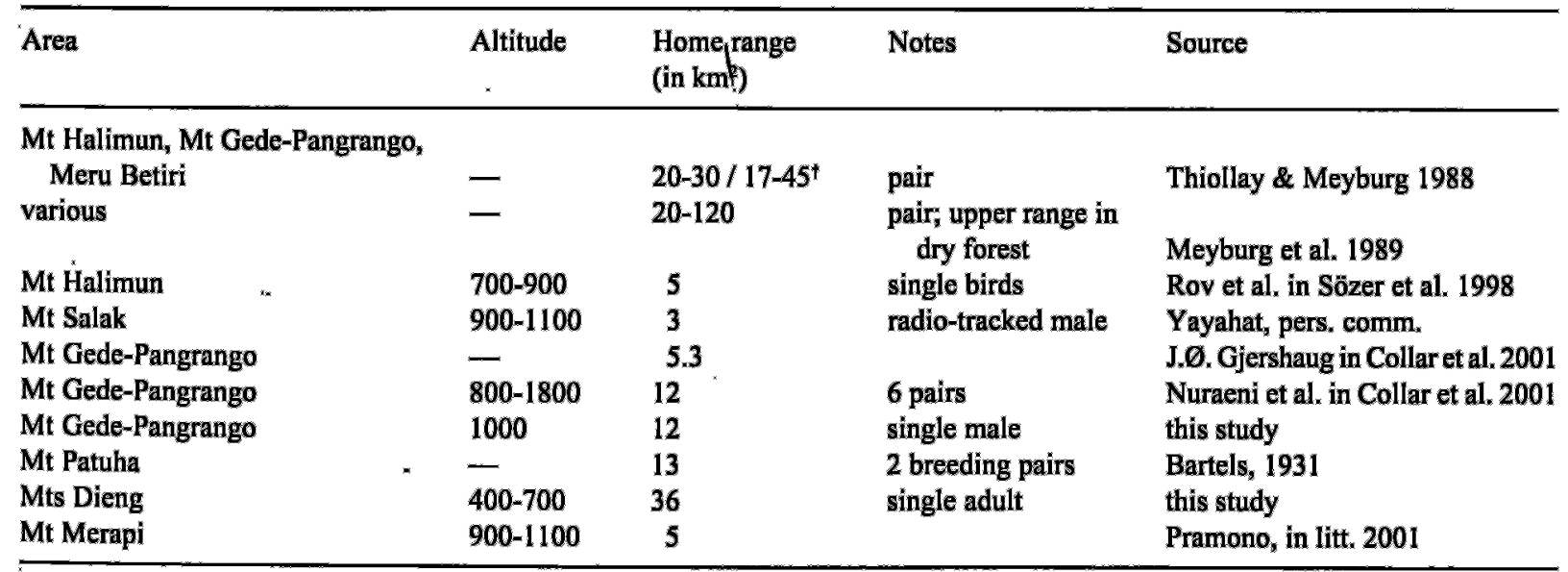

Thiollay \& Meyburg (1988) considered $20-30 \mathrm{~km}^{2}$ as the home range size of a pair of Javan Hawk-eagles, but in their calculations they used $17-45 \mathrm{~km}^{2}$. The reasons for this discrepancy are unknown. 
types of forest, such as the semi-deciduous forest of Alas Purwo. The median encounter rate for nine areas was 0.3 birds day ${ }^{-1}$, and this was not related to the size of the area (Kendall Rank Correlation Coefficient, $\tau=0.25, p>0.3$ ), i.e. encounter rates were not significantly higher in larger forest areas. Encounter rates were however strongly related to the length of the dry season in the area. In wet areas with $>30$ rainy days during the four driest consecutive months the median encounter rate was 0.8 birds day ${ }^{-1}(n=4$, range $0.5-0.9)$ whereas in dry areas ( $<30$ rainy days during the four driest consecutive months) it was 0.3 birds day ${ }^{-1}(n=5$, range $0.1-0.3)$, the difference being significant (Mann-Whitney $U$, $\mathrm{n}_{1}=4, \mathrm{n}_{2}=5, \mathrm{p}<0.05$ ).

Adult Javan hawk-eagles held territories in the least accessible, most rugged parts of tropical forest, whereas, juveniles more than adults, were occasionally found in cultivated land. Generally we encountered Javan hawk-eagles in hilly terrain, and rarely in flat plains. If occurring in rather flat regions, e.g., Ujung Kulon and Alas Purwo, the species is generally present only in the relatively most hilly parts. We recorded the species from sea level (e.g., Lebakharjo, Meru Betiri) to about 2500 $\mathrm{m}$ asl (Mt Slamet). Slightly more records originated from lowland areas $(<1200 \mathrm{~m}$ asl) than from the (sub)montane forests, i.e. 45 and 36 , respectively. Our surveys were dictated by the presence of forest and since on Java about three and a half times as much forest remains in the hills and mountains as in the lowlands (MacKinnon et al., 1982), overall we spent more time in montane areas. Hence it appears that Javan hawk-eagle occurs at higher densities in lower altitude forest.

From our survey it appears that most of the studies that have made an attempt to estimate density or homerange size were conducted in areas where the species is relatively common. Without exception, they are all situated in areas with a short dry season and are often based on the observation of single birds, a single pair or a few pairs at most (Table 2).

\section{Age composition and population size}

Figure 2 presents the age distribution as observed in the field. Immatures and juveniles make up more

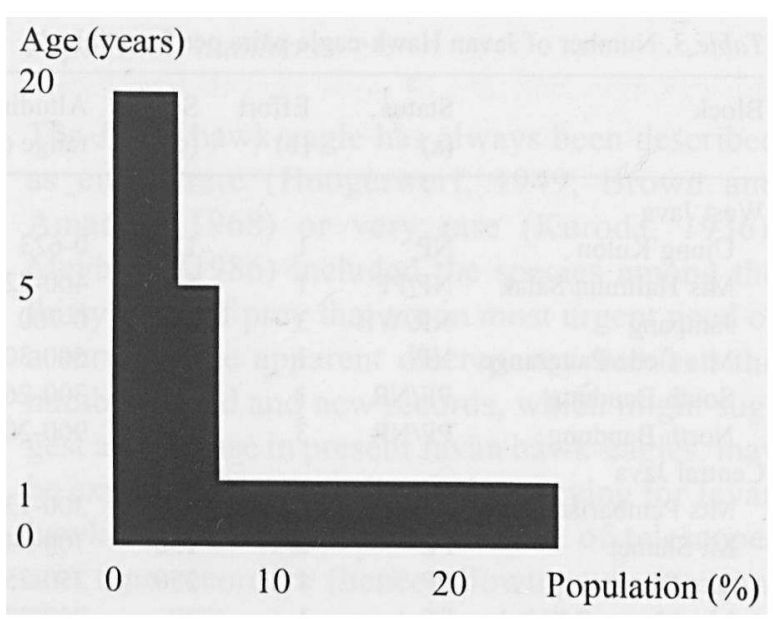

Fig. 2. Age distribution in wild Javan hawk-eagles $(\mathrm{N}=89)$.

than half of the population, and, especially the relatively large number of juveniles is apparrent. The adult : non-adult ratio for direct field observations is $43: 49$, for museum specimens $10: 14$ and for live birds observed at bird markets and zoological parks $4: 10$. These ratios are not significantly different $\left(\chi^{2}=1.7\right.$, df $\left.=2, p>0.3\right)$. Giving every observation the same weight, and assuming that they are independent, and that chances to record a non-adult or an adult are equal, the adult : non-adult ratio is $1: 1.3$.

The three parameters (climate, ruggedness and fragmentation) used to determine habitat quality were not correlated with one another (Kendall Rank Correlation Coefficient, all $\mathrm{p}>0.05$ ), nor were they correlated with size of the forest area although larger areas tended to have a higher ruggedness score (Kendall Rank Correlation Coefficient, $\tau=0.32$, $\mathrm{p}<0.06$ ). Hence, the creation of a habitat quality score as the median score of the three above mentioned parameters is justified as all three are independent. On the basis of the data presented above, we feel that, for estimating population size a conservative working density of $20-30 \mathrm{~km}^{2}$ for a pair in high quality habitat, $30-40 \mathrm{~km}^{2}$ in areas with a medium habitat quality, and $40-50 \mathrm{~km}^{2}$ in low habitat quality areas seems appropriate (cf. Collar et al., 2000).

Under the assumption that no sizeable Javan hawk-eagle habitat has been omitted in the calculations, and only mixed tropical evergreen forest contains breeding Javan hawk-eagles, the estimated number of pairs per forest area is presented 
Table 3. Number of Javan Hawk-eagle pairs per forest block.

\begin{tabular}{|c|c|c|c|c|c|c|c|c|c|}
\hline Block & $\begin{array}{l}\text { Status } \\
\text { (a) }\end{array}$ & $\begin{array}{l}\text { Effort } \\
\text { (b) }\end{array}$ & $\begin{array}{l}\text { Size } \\
\text { (c) }\end{array}$ & $\begin{array}{l}\text { Altudinal } \\
\text { range (d) }\end{array}$ & $\begin{array}{l}\text { Climate } \\
\text { (e) }\end{array}$ & $\begin{array}{l}\text { Rugged- } \\
\text { ness (f) }\end{array}$ & $\begin{array}{l}\text { Fragmenta- } \\
\text { tion (g) }\end{array}$ & $\begin{array}{l}\text { Habitat } \\
\text { quality (h) }\end{array}$ & $\begin{array}{l}\text { Breeding } \\
\text { pairs }\end{array}$ \\
\hline \multicolumn{10}{|l|}{ West Java : } \\
\hline Ujung Kulon & NP & 1 & 125 & $0-623$ & 2 & 2 & 2 & 2 & $3-4$ \\
\hline Mts Halimun/Salak & NP/PF & 1 & 500 & $400-2210$ & 1 & 1 & 1 & 1 & $16-25$ \\
\hline Jampang & NR/WR & 3 & 100 & $0-700$ & 2 & 1 & 3 & 2 & $2-3$ \\
\hline Mts Gede/Pangrango & NP & 1 & 200 & $500-3019$ & 1 & 1 & 2 & $1^{*}$ & $6-10$ \\
\hline South Bandung & PF/NR & 1 & 900 & $300-2622$ & 2 & 1 & 2 & 2 & 23-30 \\
\hline North Bandung & PF/NR & 3 & 100 & $900-2018$ & 1 & 2 & 3 & 2 & $2-3$ \\
\hline \multicolumn{10}{|l|}{ Central Java } \\
\hline Mts Pembarísan & PF & 3 & 130 & $300-1351$ & 2 & 1 & 2 & 2 & $3-4$ \\
\hline Mt Slamet & PF & 2 & 150 & $700-3418$ & 2 & 2 & 1 & 2 & $4-5$ \\
\hline Mts Dieng & PF & 1 & 250 & $250-2565$ & $1-2$ & 2 & 2 & 2 & $6-8$ \\
\hline Mts Merapi/Merbabu & PF & 1 & 80 & $950-2911$ & $1-2$ & 2 & 3 & 2 & $2-3$ \\
\hline Mt Murio & PF & 2 & 90 & $600-1602$ & 2 & 2 & 2 & 2 & $2-3$ \\
\hline \multicolumn{10}{|l|}{ East Java } \\
\hline Mts Liman/Wilis & PF & 2 & 250 & $600-2565$ & $1-2$ & 2 & 3 & 2 & $6-8$ \\
\hline Mts Kawi/Arjuno & PF/GPF & 1 & 500 & $300-2886$ & 2 & 1 & 2 & 2 & $13-17$ \\
\hline Bantur/Lebakharjo & PF & 2 & 180 & $0-250$ & 2 & 1 & 2 & 2 & $5-6$ \\
\hline \multicolumn{10}{|l|}{ Bromo/Tengger/ } \\
\hline Semeru & NP & 3 & 200 & $800-3676$ & $1-2$ & 2 & 2 & 2 & $5-7$ \\
\hline Yang highlands & PF/WR & 2 & 100 & $1600-3088$ & $1-2$ & 3 & 2 & 2 & $2-3$ \\
\hline Meru Betíri & NP & 1 & 500 & $0-1223$ & 2 & 1 & 2 & 2 & $13-17$ \\
\hline Ijen/Raung/Maelang & PF/NR & 1 & 830 & $0-3332$ & $1-2$ & 2 & 2 & 2 & $21-28$ \\
\hline Alas Purwo & NP & 1 & 160 & $0-360$ & 3 & 3 & 2 & 3 & $3-4$ \\
\hline
\end{tabular}

a. Status: NP: national park (taman nasional), GFP: grand forest park (taman hutan raya), NR: strict nature reserve (cagar alam), WS: wildlife reserve (suaka margasatwa), PF; watershed protection forest (hutan lindung). Tiny nature reserves in larger forest areas not included, b. Survey effort: $1=>10$ survey days; $2=5-10$ survey days; $3=<5$ survey days, c. Size of available habitat estimated after RePPProT (1990: scale 1: 250,000), MacKinnon et al. (1982) and our own data; see text for details, d. Altitudinal range: figures in italics represent approximate lower limits of forest (after MacKinnon et al. 1982; SvB, VN and RS, pers. obs.); forest is not always continuous over the entire altitudinal range, e. Climate type: 1:40-80 rainy days during the four driest consecutive months, $2: 20-40$ rainy days, 3: 0-20 rainy days (after van Steenis 1972), $f$. Ruggedness: $1=$ almost entirely covered with tall forest on slopes; $2=$ partially covered with tall forest on slopes; $3=$ scarcely or not covered with tall forest on slopes, g. Fragmentation: $1=$ one large, compact area; $2=$ several medium-sized, interconnected forest areas; $3=$ several small to intermediate forest areas, with or without adjacent smaller areas, h. Habitat quality: See text for details.

in Table 3. The size of each forest block, altitudind range of the forest, habitat and climatic type are given, and localities within the same forest blocks are grouped. The number of breeding pairs per forest block range between 2-3 to 23-30, with a median of 5-6 pairs, but we have to note that for a total of seven smaller areas we did not estimate forest area or population size. By including these the median population size decreases to 3-4 pairs. Following equation 1 , the estimated total breeding population size of Javan hawk-eagles is $137-188$ pairs. Given that there are 1.3 times more juveniles and immatures than there are adults, this implies a total population estimate of between 600 and 900 indi- viduals. The small areas that were not included in this estimate (e.g. Mt Karang, Mt Aseupan, Telaga Bodas - Mt Gelunggung) may add a maximum of 12-15 pairs, which leads to the total world population of the Javan hawk-eagle to be probably just short of a thousand individuals.

\section{Discussion}

\section{Density and age structure}

Our study reconfirms the importance of large forest areas in the wettest climate zone for Javan hawk- 
eagles (cf. van Balen et al. 1999). Subpopulations mostly contained only a small number of individuals and only a few forest areas harbour a population $>100$ individuals. For the first time we were able to demonstrate significant differences in encounter rate between areas with a short and nowhere marked dry season and areas with a relative longer dry season. If encounter rate is indicative for density this shows that indeed Javan hawk-eagles have a preference for rainforest areas to drier forest types. The western part of West Java, i.e. the surroundings of Bogor, has traditionally been the area where ornithologists and researchers have observed and studied Javan hawk-eagles and indeed for a long time the species was believed to be restricted to the mountains of West Java (Brown and Amadon, 1968). Recently, in response to the bird being declared 'national bird of Indonesia', more projects have been initiated to study the ecology of the Javan hawk-eagle. Unfortunately, most of them restrict their studies to a few areas where the species seems to be particularly abundant and all are situated in areas with a (very) short dry season. This may in part explain the large differences between the homerange and density estimates that have been made so far (Table 2).

The observation of eleven pairs, eight of them with single young, in late 1998, at Gede-Pangrango (Nuraeni et al. 1999 in Collar et al, 2001), suggests a high $(73 \%)$ breeding success of the Javan hawk-eagles in that population. Likewise the observation that a relatively large proportion of the wild population observed during the last 20 years consists of juveniles and immatures indicates relatively high levels of recruitment. The high numbers of immatures and juveniles observed at bird markets are reason for concern, especially when seen in the context of the low reproductive output of the eagles (Nijman et al. 2000). On the other hand, this might suggest that the resident adult population is relatively unaffected by bird catchers. Removal of breeding adults has a much larger effect on the survival chances of the total population than that of immatures and juveniles.

\section{Population numbers}

The Javan hawk-eagle has always been described as either rare (Hoogerwerf, 1949; Brown and Amadon, 1968) or very rare (Kuroda, 1936). Meyburg (1986) included the species among the thirty birds of prey that are in most urgent need of a survey. The apparent discrepancy between the number of old and new records, which might suggest an increase in present Javan hawk-eagles, may be explained by more directed surveying for Javan hawk-eagles, supported by the use of telescopes and tape-recorders (hence allowing species confirmation). The increased accessibility to formerly unexplored habitat has also undoubtedly contributed to more birds having been observed. Finally, more sophisticated field identification techniques have contributed to a larger number of positive identifications.

The destruction and fragmentation of the once continuous forest on Java is widely considered the major threat to the survival of the Javan hawk-eagle (Thiollay and Meyburg, 1988; Collar et al., 1994; Sôzer et al., 1998). The species was believed to be divided in two populations, separated by a 375-670 $\mathrm{km}$ wide gap of non-forest area in the central part of Java (Thiollay and Meyburg; 1988). Contra to Thiollay and Meyburg (1988), however, we did find substantial areas of remaining forest in the central part of Java, and indeed it is estimated that the Central Javan gap, sustains about $15 \%$ of the total population. The central Javan populations may provide a vital link between the larger populations in the eastern and western part of the island.

In July-August 1986 Thiollay and Meyburg (1988) visited the island of Java on a three-week raptor survey. In three of the five reserves visited, the presence of Javan hawk-eagles was confirmed, and the total number of birds was estimated at not more than 60 breeding pairs (Meyburg et al., 1989). Based on the discovery of additional localities this number was adjusted to 67-81 (van Balen and Meyburg, 1994) and then 81-108 pairs (Sözer and Nijman, 1995). Our new population estimate is again considerably higher, owing to new localities, a more accurate estimation of forest size, and differentiation in habitat quality and density. Collar et al. (2000) discussed the different population estimates 
of Javan hawk-eagles over the last decades. Erroneously, they considered most sites where Setiadi et al. (2000) recorded the species to constitute forest sites previously not included in population estimates, and, cautiously, suggested that this may add some 42 pairs (i.e. some 190 birds) to the total population. In fact, all but one area (Masigit Kareumbi) were included in previous estimates (i.e. in the present estimate the "new' sites are all included in 'South Bandung': see Table 3).

Despite various assumptions we had to make, we are confident that our new population estimate is the most accurate currently possible. As such, the present study provides a baseline, against which future research and management can be set. At the same time, more recent satellite imageries or aerial photo mapping will allow a more precise estimate of the extent of forest cover on Java and more long-term and focussed field observations will provide a better insight in the density of Javan hawk-eagle. This in turn will allow a better estimate of its numbers. However, it is unlikely that greater precision will drastically change our conclusions or recommendations.

\section{Suggestions for further research and improved conservation}

Although the present study attempted to obtain data on a number of basic population parameters, it has to be concluded that key information on the ecology of the Javan hawk-eagles is still lacking. The basic knowledge needs to be improved as a basis for future management of the species and its habi + tat; the data provided in the present study can then be used as a baseline.

Data presented in this and previous research (van Balen et al. 2000) makes it likely that the survival chances of Javan hawk-eagles are related to forest area size and habitat quality. Many populations are probably too small to survive in the long run if they were not occasionally augmented by individuals from nearby populations. Given that breeding adults are strongly territorial this suggests a role for juveniles as dispersal agents and indeed juveniles are more frequently observed outside forest areas than adults. Yet we have limited knowledge on the dispersal abilities of juveniles (or adults for that matter). We presented the age structure of Javan hawk-eagles based on field observations from a relative long period over a large number of areas. We recommend that other researchers start ageing the Javan hawk-eagles they observe: this is rarely done, yet it is vital to our understanding of the demography, age-structure, and recruitment of the population as well as for our understanding of agerelated habitat preferences.

We encountered Javan hawk-eagles significantly less frequent in areas with a long dry season compared to areas with a short dry season. If this reflects density, as we think it does, although admittedly crude this is the first firm data on density differences related to physical habitat characters. We suggest other researcher to expand on this, and start exploring the underlying factors of density differences between areas, including more detailed measurements of productivity, persecution pressure, effects of forest area and degree of isolation.

For the effective conservation of Javan hawkeagles it is vital to expand on the present reserve system on Java (cf. Sözer et al. 1998). Although the present network of forest areas has been sufficient for the species to make it to the 21 st century, and breeding seems to take place in even the smallest forest areas where it occurs (van Balen et al. 2000), in order to increase the species' survival prospects implementing a strategy in which more forest areas are included in the protected area network seems imperative. The proclamation of the Javan hawk-eagle as Indonesia's national rare bird, has not brought the species more protection. Quite to the contrary, in fact the previously anonymous eagle might have become more attractive for malevolent aviculturists and zoos, and as such the proclamation might have directly decreased its survival prospects (cf. Collar et al. 2001). So far this has not been counterbalanced by tougher law enforcement or increasing protection of the wild population, and there seems to be a lack of serious and effective commitment and political support (at all levels) for the conservation of Indonesia's national bird. We argue strongly for the gazettment of a series of reserves, either under national or regional control, including the Mts Dieng and the extended Ijen-Raung reserve. 


\section{Acknowledgements}

We thank the Indonesian Institute for Sciences (LIPI) and the Directorate General of Forest Protection and Nature Conservation (PHPA), for permission to conduct field research. BirdLife International - Indonesia Programme is thanked for logistic support and the use of their facilities. Grants were received from the Van Tienhovenstichting, Wereld Natuurfonds, Zoologisch Insulinde Fonds, Gresshoff's Rumphiusfonds, FONA, World Working Group of Birds of Prey and Owls, the American Federation of Aviculture and the Fauna \& Flora Preservation Society, the Oriental Bird Club, the J.C. van der Hucht Fonds, P.A. Hens Memorial Fund and the Martina de Beukelaar Stichting. The bird curators of the National Museum of Natural History in Leiden (Dr G.F. Mees, Dr R. Dekker) and the Museum Zoologicum Bogoriense (especially Dr Asep Adikerana, Ir Daryono, Ir Sudaryanti and Dr D.M. Prawiradilaga) provided access to the specimens of their collections. Messrs I. Setiawan and $A$. Setindi were our companions during part of the surveys. The late Mr H. Bartels, Dr P.J.H. van Bree, Dr P. Jepson, Dr.B.-U. Meyburg, Prof. dr. S. Somadikarta, Prof, dr. K.H. Voous and Dr J. Wattel provided valuable advice throughout the project. P. Jepson, Prof. dr. S.B.J. Menken, Dr A.Ø. Mooers and Prof. dr. H.H.T. Prins commented on earlier drafts of the paper.

\section{References}

Balen S van. 1988. Forest fragmentation and the survival of forest birds in Java: a preliminary report. In: Proceedings Deutscher Akademischer Austauschdienst Nachkontakt Seminar. Bogor, 9-11 December 1987, 115-165.

Balen S van. 1998. Tropical forest raptors in Indonesiax Recent information on distribution, status, and conservation. J. Raptor Res. 32; 56-63.

Balen S van, Meyburg B-U. 1994. The Java Hawk Eagle Spizaetus bartelsi: results of recent research on distribution, status and ecology. In Meyburg B-U, Chancellor RD, eds. Raptor Conservation Today. Berlin, London and Paris: WWGBP and The Pica Press, 89-92.

Balen S van, Nijman V, Prins HHT. 2000. The Javan Hawkeagle: misconceptions about rareness and threat. Biol. Conserv. 96: 297-304.

Balen S van, Nijman V, Sözer R. 1999. Distribution and conservation of the Javan Hawk-eagle Spizaetus bartelsi. Bird Conserv. Intern. 9: 333-349.

Bartels E. 1931. Vogels van Kole Beres. Natuurwet. Tijdschr. Ned. Indië 91: 308-348.

Bennett PM, Owens IPF. 1997. Variation in extinction risk among birds: Chance or evolutionary predisposition? Proc. Royal Soc. London Series B 264: 401-408.

Brown L, Amadon D. 1968. Eagles, hawks and falcons of the world, 2 Vols. Feltham: Country Life Books.

Collar NJ, Andrew P. 1988. Birds to watch: the ICBP world check-list of threatened birds. Cambridge: International Council for Bird Preservation.
Collar NJ, Andreev JV, Chan S, Crosby MJ, Subramanya S, Tobias JA, eds. 2001. Threatened birds of Asia: the BirdLife International red data book. Cambridge: BirdLife International.

Clark WS. 1994. Species accounts, family Accipitridae (hawks and eagles). In Handbook of birds of the world, Vol 2, New World Vultures to Guineafowl. Hoyo J. del, Elliot A, Sargatal J, eds. Barcelona: Lynx edicions, 106-205.

Davies KE, Margules CR, Lawrence JE 2000. Which traits of species predict population declines in experimental forest fragments? Ecology 81: 1450-1461.

Fagan WF, Meir E, Prendergast J, Folarin A, Karieva P. 2001. Characterizing population vulnerability for 758 species. Ecology Letters 4: 132-138.

Harris LD 1984. The fragmented forest. Chicago and London: The University of Chicago Press.

Hilton-Taylor C. 2000. IUCN red list of threatened species. Gland and Cambridge: International Union for the Conservation of Nature and natural resources.

Hoogerwerf A. 1949. De avifauna van Tjibodas en omgeving, inclusief het natuur-monument Tjibodas-G. Gede. Bogor: Koninklijke Plantentuin van Indonesië.

Kuroda N. 1936. Birds of Java, 2. Non passeres. Tokyo: published by the author.

MacKinnon JR, Smiet AC, Artha MA. 1982. A national conservation plan for Indonesia, Vol. III Java and Bali. Bogor: FAO. [UNDP/FAO FO/INS/78/061 Field report 36].

McKinney ML. 1997. Extinction vulnerability and selectivity: Combining ecological and paleontological views. Ann. Rev. Ecol. Systematics 28: 495-516.

Meyburg B-U. 1986. Threatened and near-threatened diurnal birds of prey of the world. Birds of Prey Bull. 3: 1-12.

Meyburg B-U, van Balen S, Thiollay J-M, Chancellor RD. 1989. Observations on the endangered Java Hawk Eagle Spizaetus bartelsi. In Meyburg B-U, Chancellor RD, eds. Raptors in the modern world. Berlin, London and Paris: WWGBP, 279-299.

Myers N, Mittermeier RA, Mittermeier CG, da Fonseca GAB, Kent J. 2000. Biodiversity hotsports for conservation priorities. Nature 403: 853-858.

Newton I. 1979. Population ecology of raptors. Berkhamsted* Poyser.

Newton I. 1991. Population limitation in birds of prey: a comparative approach. In Perrins CM, Lebreton L-D, Hirons GJM, eds. Bird population studies: relevance to conservation and management. Oxford, New York, Tokyo: Oxford University Press, 3-21.

Nijman V, Sözer R. 1998. Field identification of the Javan Hawk-eagle Spizaetus bartelsi. Forktail 14: 13-16.

Nijman V, van Balen S, Sözer R. 2000. Breeding biology of Javan Hawk-eagle Spizaetus bartelsi in West Java, Indonesia. Emu 100: 125-132.

RePPProT. 1990. The land resources of Indonesía: a national overview. Regional physical planning programme for transmigration. Jakarta: Ministry of Transmigration and Land Resources, Department NRI, UK Overseas Development Administration. 
Setiadi AP, Rakhman Z, Nurwatha PF, Muchtar M, Raharjaningtrah W. 2000. Distribusi, populasi, ekologi dan konservasi Elang Jawa Spizaetus bartelsi Stresemann 1924 di Jawa Barat bagian selatan. BP / FFI / BirdLife International / YPAL-HIMBIO UNPAD, Bandung.

Smiet AC. 1990. Forest ecology on Java: conversion and usage in a historical perspective. $J_{*}$ Trop. Forest $S c$. 2; 286-302.

Smiet AC. 1992. Forest ecology on Java: human impact and vegetation of montane forest. $J$. Trop. Ecol. 8: 129-152.

Sözer R, Nijman V. 1995. Behavioral ecology, distribution and conservation of the Javan Hawk-eagle Spizaetus bartelsi Stresemann, 1924. Versl. Techn. Gegev. 62: 1-122.

Sözer R, Nijman V, Setiawan I, van Balen S, Prawiradilaga, DM, Subijanto J. 1998. Javan Hawk-eagle recovery plan. Bogor: KMNLH/PHPA/LIPL/BirdLife International-Indonesia Programme.

Steenis CGGJ van, Schippers-Lammertse AF. 1965. Concise plant-geography of Java. In Backer CA, Bakhuizen van den Brink RC, eds. Flora of Java, Vol. 2. Groningen: Noordhoff, 1-72.

Steenis CGGJ van. 1972. The mountain flora of Java. Leideñ: Brill.

Terborgh J. 1988. The big things that run the world - A sequel to Wilson, E.O. Conserv. Biol. 2: 402-403.

Thiollay J-M. 1985. Falconiformes of tropical rainforest: a review. ICBP Technical Publ. 5: 155-165.

Thiollay J-M, 1994. A world review of tropical forest raptors: current trends, research objectives and conservation strategy. In Meyburg B-U, Chancellor RD, eds. Raptor Conservation Today. Berlin, London and Paris: WWGBP and The Pica Press, 231-239.

Thiollay J-M, Meyburg B-U. 1988. Forest fragmentation and the conservation of raptors: survey on the island of Java. Biol. Conserv. 44: 229-250.

Wells DR. 1985. The forest avifauna of Western Malesia and its conservation. ICBP Technical Publ. 4: 213-232.

Whitten T, Soeriantmadja RE, Afiff SA. 1996. The ecology of Java and Bali. The Ecology of Indonesia Series II. Singapore: Periplus.

Received: 2 October 2001

\section{Appendix 1.}

Gazetteer of all localities mentioned in the text and tables. For large reserves and mountains coordinates refer either to the centre of the area or to that part where Javan Hawk-eagles have been observed. Note that in many of the Javanese names the 0 and a are exchangeable (e.g. Linggo / Lingga, Lenggosono / Lenggasana).

Alas Purwo [114 $23^{\circ} \mathrm{E}, 8^{\circ} 43^{\prime} \mathrm{S}$ ], $620 \mathrm{~km}^{2}$ large national park in the south-easternmost part of Java; largely covered in dry deciduous forest. Javan hawk-eagles are scarce and only occur in the hilly part of the reserve. Also known as Banyuwangi Selatan.
Bantur $\left[112^{\circ} 35^{\prime} \mathrm{E}, 8^{\circ} 25^{\prime} \mathrm{S}\right]$, strip of good lowland forest (c. 50 $\mathrm{km}^{2}$ ) on the southcoast of Java, more or less continues with the Lebakharjo forest to the east.

Dieng Mountains [109 $49^{\prime} \mathrm{E}, 7^{\circ} 09$ 'S], $255 \mathrm{~km}^{2}$ large forest area on the northern and north-western part of the Dieng plateau. Natural forest is found from c. $300-2565 \mathrm{~m}$ asl and Javan hawk-eagles have been observed throughout.

Ijen Highlands [114 $\left.{ }^{\circ} 02^{\prime} \mathrm{E}, 8^{\circ} 07^{\prime} \mathrm{S}\right]$, easternmost volcano complex with some $1400 \mathrm{~km}^{2}$ of forest proposed as conservation area; Mt Raung (3332 m) is the highest peak in the area. The forests are more or less continuous with those of the Meru Betiri National Park to the south. Javan hawk-eagles have only been observed in the eastern part but are probably present throughout the area.

Jampang $\left[106^{\circ} 37^{\prime} \mathrm{E}, 7^{\circ} 16^{\prime} \mathrm{S}\right]$, rugged area in the south-western corner of West Java. The area is relatively sparsely populated and patches of primary and, more commonly, secondary forest are found scattered throughout. Javan hawk-eagles have been collected in 1928 and observed in the early 1980 's.

Lebakharjo $\left[112^{\circ} 51^{\prime} \mathrm{E}, 8^{\circ} 22^{\prime} \mathrm{S}\right]$. Important, as yet unprotected, $130 \mathrm{~km}^{2}$ lowland forest area on the south coast of East Java. Continuous with the Bantur forest to the west, and separated from the forests on Mt Semeru by a road and plantations. Also known as Teluk Lenggosono / Lenggasana.

Linggo Asri $\left[109^{\circ} 35^{\prime} \mathrm{E}, 7^{\circ} 06^{\prime} \mathrm{S}\right]$, resort on the north-western part of the Dieng Mountains. Javan hawk-eagles have been studied here intermittedly from 1994 onwards.

Kawah Kamojang [107 $48^{\prime} \mathrm{E}, 7^{\circ} 08^{\prime} \mathrm{S}$ ], $80 \mathrm{~km}^{2}$ large nature reserve and recreation forest centred around a crater on $\mathrm{Mt}$ Papandayan.

Masigit-Kareumbi $\left[107^{\circ} 57^{\circ} \mathrm{E}, 6^{\circ} 57^{\prime} \mathrm{S}\right]$, c. $125 \mathrm{~km}^{2}$ large forest area, in part included in a wildlife reserve, situated east of Bandung and not to be confused with Mt Masigit $\left[107^{\circ} 19 \mathrm{E}\right.$, $7^{\circ} 07$ S']. Two pairs of Javan hawk-eagle observed by Setiadi et al. (2000).

Meru Betírí $\left[113^{\circ} 48^{\prime} \mathrm{E}, 8^{\circ} 28^{\prime} \mathrm{S}\right.$ ], c. $500 \mathrm{~km}^{2}$ large National Park, once famous for its last Javan tigers Panthera tigris, and now still an important reserve for the preservation of Javan wildlife. Javan hawk-eagles are commonly observed, especially in the central sections.

Mt Arjuno [112 $34^{\prime} \mathrm{E}, 7^{\circ} 45^{\prime} \mathrm{S}$ ], a large mountain c. $65 \mathrm{~km}$ south of Surabaya, and still extensively covered in forest, especially above $1000 \mathrm{~m}$ line. The forest consists of a mosaic of partially regenerating former coffee plantations, partially degraded lowland, hill and montane forest in varying degrees of disturbance. Javan hawk-eagles regularly observed on the southern slopes near Ratu Soerjo and Cangar.

Mt Aseupan [105 $\left.57^{\prime} \mathrm{E}, 6^{\circ} 17^{\prime} \mathrm{S}\right]$, isolated mountain near Java's west coast. Javan hawk-eagles have been observed near the Curug Gendang waterfalls on the western slopes.

Mt Bromo/Tengger/Semeru [112 $\left.56^{\circ} \mathrm{E}, 8^{\circ} 02^{\prime} \mathrm{S}\right], 576 \mathrm{~km}^{2}$ large national park famous for its large "sea of sand" in the caldera and Mt Semeru for being Java's tallest mountain (3676 m asl). The southern slopes are still extensively covered in forest but faunistically remain largely unexplored. Javan hawk-eagles have been observed by Nursaid et al. (pers. comm.).

Mt Burangrang [107 $34^{\prime} \mathrm{E}, 6^{\circ} 45^{\prime} \mathrm{S}$ ], small $\left(27 \mathrm{~km}^{2}\right)$ forest area but more or less continuous with those on Mt Tangkuban Perahu. 
Mt Cupu-Simembut $\left[109^{\circ} 28^{\prime} \mathrm{E}, 7^{\circ} 14^{\prime} \mathrm{S}\right]$, small fragment of forest west of the Dieng mountains.

Mt Gede Pangrango [107 $00^{\prime} \mathrm{E}, 6^{\circ} 45 \mathrm{~S}$ ], famous for its $150 \mathrm{~km}^{2}$ large national park that includes the botanical gardens of Cibodas and probably is the best explored mountain in Indonesia. Javan hawk-eagles commonly observed throughout.

Mt Halimun [106 $300^{\prime} \mathrm{E}, 6^{\circ} 40^{\prime}$ ], c. $500 \mathrm{~km}^{2}$ large national park with in its centre the Nirmala tea estate. From the mid 1980's Javan hawk-eagles are regularly observed both from the estate and along its borders.

Mt Karang [106 $\left.05^{\prime} \mathrm{E}, 6^{\circ} 16^{\prime} \mathrm{S}\right]$, small long-time ísolated forest area on a mountain near the west coast of Java. Several Javan hawk-eagles, including juveniles, have been observed.

Mts Kawi-Kelud [112 $23^{\prime} \mathrm{E}, 7^{\circ} 56^{\prime} \mathrm{S}$ ], twin volcano c. $40 \mathrm{~km}$ south-east of Kediri, still extensively covered in, largely degraded, forest. Forests is more or less continuous through a mosaic of plantations and regenerating former coffee plantations with those on Mt Arjuno.

Mts Liman-Wilis [111 $\left.57^{\circ} \mathrm{E}, 7^{\circ} 50^{\prime} \mathrm{S}\right]$, complex of four mountains of which Mt Liman ( $2563 \mathrm{~m}$ asl) is the tallest. Covered in a mixture of degraded and still relatively undisturbed forest. Javan hawk-eagles observed throughout.

Mt Merapi $\left[110^{\circ} 26^{\prime} \mathrm{E}, 7^{\circ} 28^{\prime} \mathrm{S}\right]$, an active volcano some $30 \mathrm{~km}$ north of Yogyakarta. Forest in some parts greatly disturbed by the continuing flow of lava and regular enuptions and human activities, but rather pristine in other parts. Note that there is also a Mt Merapi in the ljen Highlands.

Mt Merbabu [110 $\left.20^{\prime} \mathrm{E}, 7^{\circ} 20^{\prime} \mathrm{S}\right]$, twin volcano of Mt Merapi, with the forest being more disturbed. Javan hawk-eagles have not been recorded but the area probably constitute one population with those on Mt Merapi

Mt Muriah [110 $\left.53^{\prime} \mathrm{E}, 6^{\circ} 36^{\prime} \mathrm{S}\right]$, isolated mountain on the north coast of Central Java, separated from the other mountains on the central Javan longitudinal axis by a large dry limestone area largely covered in teak Tectona grandis plantations; despite its isolated position Javan hawk-eagles (both adult and juvenile) are present. Also known as Mt Murio.

Mt Papandayan [107 $\left.45^{\circ} \mathrm{E}, 7^{\circ} 05^{\prime} \mathrm{S}\right]$, disturbed montane forest totalling some $150 \mathrm{~km}^{2}$, including Kawah Kamojang.

Mt Patuha [107 $\left.15^{\circ} \mathrm{E}, 7^{\circ} 19^{\prime} \mathrm{S}\right]$, mountain c. $30 \mathrm{~km}$ south-west of Bandung with forest largely confined to those parts above the $1000 \mathrm{~m}$ line. The Koleberes tea estate of the Bartel's family was situated on the south-western slopes of this mountain and here observations of several breeding pairs were made in the 1920-1930's. More recently, Javan hawk-eagles have been observed near Brussel, on the western slopes, by Setiadi et al. (2000).
Mt Raung, see Ijen Highlands

Mt Salak [ $106^{\circ} 42^{\prime} \mathrm{E}, 6^{\circ} 44^{\prime} \mathrm{S}$ ], mountain c. $24 \mathrm{~km}$ south of Bogor; Javan hawk-eagles have been regularly observed here and recently the eagles have been studied by a Norwegian-Indonesian team of scientists.

Mt Sawal $\left[108^{\circ} 15^{\prime} \mathrm{E}, 7^{\circ} 12^{\prime} \mathrm{S}\right]$, small $\left(50 \mathrm{~km}^{2}\right)$ nature reserve containing still relatively good forest. Javan hawk-eagles have been observed on this mountain by Setiadi et al. (2000).

Mt Semeru, see Mt Bromo-Tengger-Semeru.

Mt Slamet [109 $\left.11 \mathrm{E}, 7^{\circ} 16^{\prime} \mathrm{S}\right]$, tall $(3418 \mathrm{~m})$ volcano still exten- sively covered in forest, especially above the $1000 \mathrm{~m}$ line, but descending to $700 \mathrm{~m}$ asl on the southern slopes. Javan hawk-eagles were studied here in 1994-1995 and observed from 700-2500 $\mathrm{m}$ asl.

Mt Tangkuban Perahu $\left[107^{\circ} 37^{\circ} \mathrm{E}, 6^{\circ} 44\right.$ 'S , well known volcano just north of Bandung; largely deforested but on its western slopes some lowland forest remains that is more or less continuous with that on Mt Burangrang. Also known as Tangkubanperahu; note that there is also a small reserve called Tangkuban Perahu in Jampang [106 $\left.35^{\circ} \mathrm{E}, 7^{\circ} 00^{\prime} \mathrm{S}\right]$

Mt Tilu [107 $\left.30^{\prime} \mathrm{E}, 7 \times 10^{\prime} \mathrm{S}\right]$, mountainous area with several peaks and a forest area totalling some $250 \mathrm{~km}^{2}$. Forest is more or less centinuous with that on other mountains including $\mathrm{Mt}$ Patuha.

Mt Ungaran $\left[110^{\circ} 22 \mathrm{E}, 7^{\circ} 09^{\prime} \mathrm{S}\right]$, small mountain south of Semarang, and covered with some $55 \mathbf{~ k m}^{2}$ forest. Javan hawkeagles have been observed once on this mountain in 1994 (M. Linsley pers. comm.).

Pasir Pogor $\left[106^{\circ} 47^{\prime} \mathrm{E}, 6^{\circ} 42^{\prime} \mathrm{S}\right]$, valley on the western slopes of Mt Pangrango where Javan hawk-eagles were studied in 19941995, see Mt Gede-Pangrango.

Pembarisan Mountains [108 $39^{\circ} \mathrm{E}, 7^{\circ} 10^{\prime} \mathrm{S}$ ], a large lowland forest area (c. $130 \mathrm{~km}^{2}$ ) on the border of West and Central Java. Javan hawk-eagles observed near Mt Segara in the eastern part of the area.

Telaga Bodas - Mt Galunggung [108 $\left.04^{\prime} \mathrm{E}, 7^{\circ} 14^{\prime} \mathrm{S}\right]$, a c. $60 \mathrm{~km}^{2}$ large forest area where Javan Hawk-eagles have been observed near the Telaga Bodas lake and near Cipanas on Mt Galunggung (Setiadi et al. 2000)

Ujung Kulon [105 ${ }^{\circ} 19^{\prime} \mathrm{E}, 6^{\circ} 46^{\prime} \mathrm{S}$ ], $760 \mathrm{~km}^{2}$ large national park famous for its last Javan rhinos Rhinoceros sondaicus, Javan hawk-eagles probably only occur in the mainland section of the park.

Yang Highlands $\left[113^{\circ} 36^{\circ} \mathrm{E}, 8^{\circ} 01^{\prime} \mathrm{S}\right]$, a highland area with $\mathrm{Mt}$ Argopuro $(3088 \mathrm{~m})$ as its highest peak, and once famous for its large herds of Javan deer Cervus timorensis. Also known as Hyang. 